\title{
Lymphoid Lesions of the Head and Neck: A Model of Lymphocyte Homing and Lymphomagenesis
}

Elaine S. Jaffe, M.D.

Hematopathology Section, Laboratory of Pathology, National Cancer Institute, Bethesda, Maryland

Lymphoid lesions of the head and neck mainly affect the nasopharynx, nasal and paranasal sinuses, and salivary glands. These three compartments each are affected by a different spectrum of lymphoid malignancies and can serve as model for mechanisms of lymphomagenesis. The type of lymphoma seen reflects the underlying biology and function of the particular site involved. The nasopharynx and Waldeyer's ring are functionally similar to the mucosal associated lymphoid tissue (MALT) of the gastrointestinal tract and are most commonly affected by B-cell lymphomas, with mantle cell lymphoma being a relatively frequent subtype. The most prevalent lymphoid lesion of the salivary gland is lymphoepithelial sialadenitis, associated with Sjögren's syndrome. Lymphoepithelial sialadenitis is a condition in which MALT is acquired in a site not normally containing lymphoid tissue. Patients with Sjögren's syndrome are at increased risk to develop B-cell lymphomas, most commonly MALT lymphomas. The nasal and paranasal sinuses are the prototypical site for the development of extranodal natural killer (NK) /T-cell lymphoma, nasal type. This condition must be distinguished from other conditions causing the clinical picture of lethal midline granuloma, including Wegener's granulomatosis and infectious disorders. Lymphomatoid granulomatosis is common in the lung but is rarely seen in the midline facial structures.

KEY WORDS: B-cell, Epstein Barr virus, Follicular lymphoma, Immunophenotyping, Lymphocyte homing, Lymphoma, Lymphomagenesis, MALT lymphoma, NK-cell lymphoma, T-cell.

Mod Pathol 2002;15(3):255-263

Copyright () 2002 by The United States and Canadian Academy of Pathology, Inc.

VOL. 15, NO. 3, P. 255, 2002 Printed in the U.S.A.

Date of acceptance: September 27, 2001.

Address reprint requests to: Elaine S. Jaffe, M.D., Building 10, Room 2N202, 10 Center Drive MSC-1500, Bethesda, MD 20892; e-mail: ejaffe@mail.nih.gov; fax: 301-402-2415.
Lymphomagenesis is not a random event but is usually site specific. It is dependent on lymphocyte homing, as well as the underlying biology and function of the resident lymphoid tissues. The head and neck region contains several compartments: the nasopharynx, nasal and paranasal sinuses, and salivary glands, each of which is affected by a different subset of benign and neoplastic lymphoid proliferations (Table 1). These three sites can serve as a model of lymphomagenesis that can be extended to other organ systems. Indeed, the head and neck region can serve as a microcosm for understanding the principles of lymphoma classification and the distribution of lymphoma subtypes in other organ systems.

The nasopharynx normally contains abundant lymphoid tissue. This site is functionally equivalent to the lymphoid tissue of the gastrointestinal tract or mucosal-associated lymphoid tissue (MALT). The most common benign process is follicular hyperplasia, and the most common lymphomas are the "small B-cell lymphomas," most commonly mantle cell lymphoma. By contrast, the nasal region and paranasal sinuses do not contain lymphoid tissue normally. NK/T-cell lymphomas are most common in this site, nearly always associated with Epstein-Barr virus (EBV). The prevalence of EBV in this subset of lymphomas may relate to the fact that the nasopharynx is a reservoir for EBV infection. Interestingly, however, most nasopharyngeal lymphomas are negative for EBV sequences.

The salivary gland does not normally contain lymphoid tissue but is a site predisposed to the acquisition of acquired MALT upon appropriate antigenic stimulation. It is a frequent target in patients with autoimmune disease, such as Sjögren's syndrome (SS). The most common lymphoma of the salivary gland is MALT lymphoma.

\section{NASOPHARYNGEAL LYMPHOID HYPERPLASIA AND LYMPHOMA}

As Waldeyer's ring is the site of abundant lymphoid tissue, the nasopharyngeal lymphoid tissues can be the sites of both lymphoid hyperplasia and 
TABLE 1. Common Lymphoid Lesions of the Head and Neck

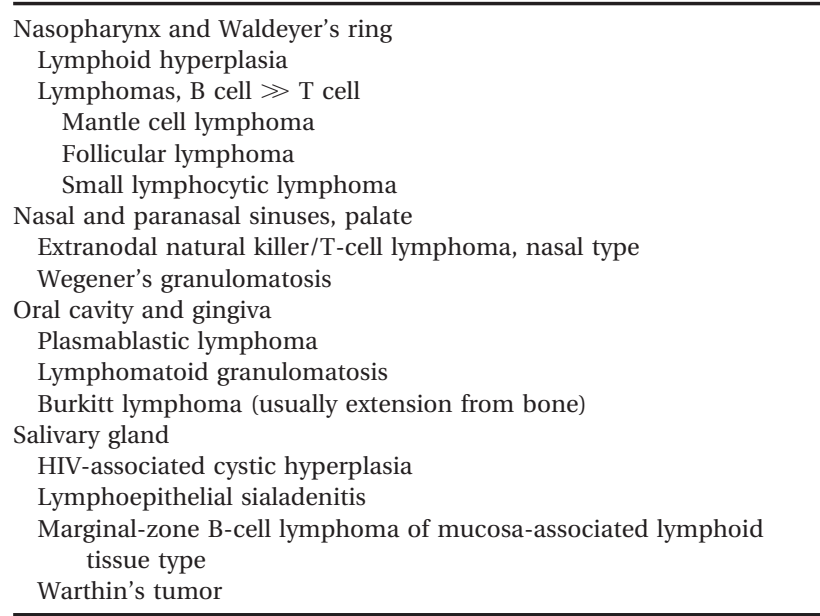

lymphoma. In many respects, the lymphoid tissue of the nasopharynx is functionally similar to the lymphoid tissues of the gastrointestinal tract and is considered part of the MALT system. Follicular hyperplasia is the most common pattern of lymphoid reaction seen. Lymphocytes often infiltrate the overlying epithelium, producing lymphoepithelial lesions, and should not be considered suspicious for evolving lymphomas. Lymphoepithelial lesions are common in sites containing normal MALT, such as the tonsil and ileum. In contrast, when lymphoepithelial lesions are seen in acquired MALT, such as in the stomach, they are more often an indication for an evolving lymphoproliferative process (1).

The most common lymphomas of the nasopharynx are the small B-cell lymphomas, mantle cell lymphoma (MCL), small lymphocytic lymphoma/ chronic lymphocytic leukemia (SLSL/CLL), and follicular lymphoma (FL; Table 2). The histologic and immunophenotypic features of these lymphomas mirror those of other sites.

MCL is among the more common lymphomas affecting the nasopharynx. It frequently involves the gastrointestinal tract, producing polypoid lesions throughout the small bowel. This pattern of gastrointestinal tract involvement has been referred to as lymphomatous polyposis (2). Twenty percent of patients with MCL present with overt gastrointestinal tract involvement, but with endoscopic evaluation, the incidence increases to $88 \%(3,4)$. As the nasopharynx is functionally and developmentally linked to the gastrointestinal tract, it is not surprising that this site is commonly involved as well. Waldeyer's ring is involved at presentation in $20 \%$ of patients, but the incidence may be greater with a thorough ear, nose, and throat exam and blind biopsies of nasopharyngeal lymphoid tissue (3). The overlying mucosal epithelium is commonly undisturbed. MCL is composed of CD5+, B-cells,
TABLE 2. World Health Organization Classification of Lymphoid Neoplasms

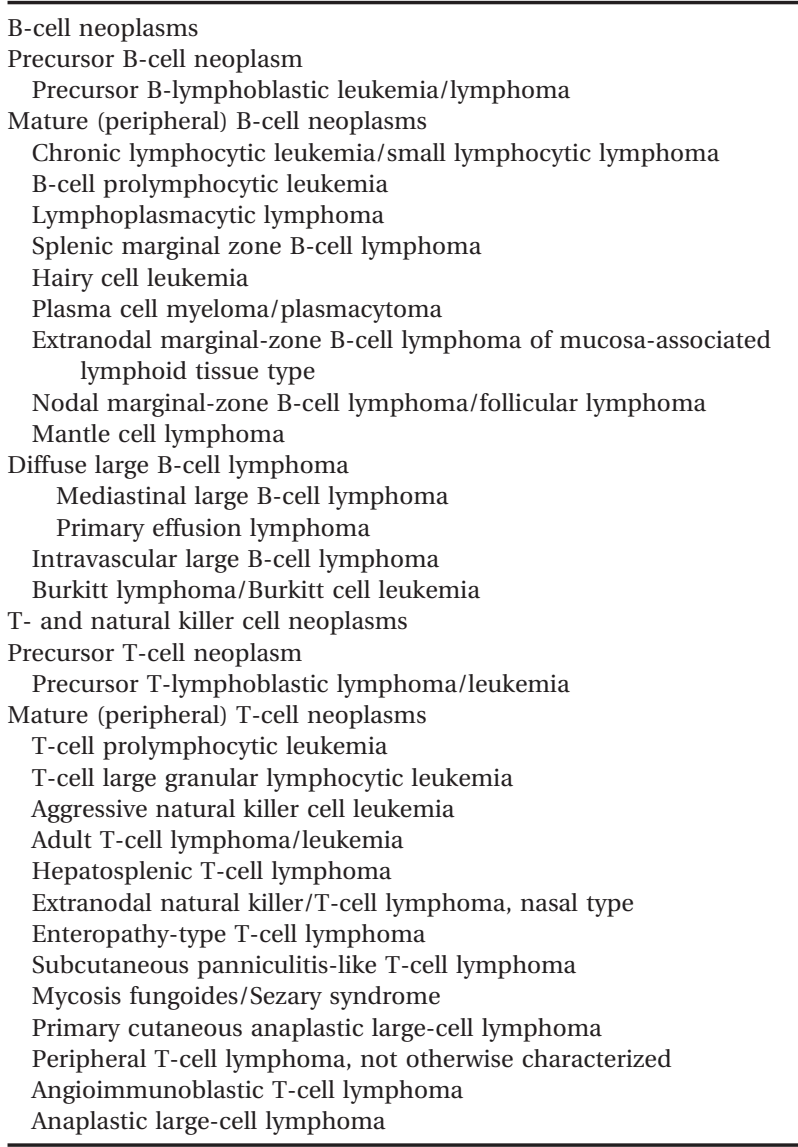

usually negative for CD23. They are cyclin D1 positive as a result of the associated chromosomal translocation, $\mathrm{t}(11 ; 14)$ (5). Immunophenotypic studies are very helpful in differential diagnosis, as especially in small biopsy specimens, morphologic details of architecture and cytology may be limited.

Follicular lymphoma is not uncommon in the palatine tonsils but is more infrequent in the nasopharynx. Although follicular lymphomas are generally rare in children, the nasopharyngeal and palatine tonsils are among the most common sites of follicular lymphomas in children (6). In contrast to follicular lymphomas in adults, these tumors are usually $b c l-2$ protein negative and lack $B C L-2$ gene rearrangements (Table 3 ). They are typically Grade 3 , with a predominance of centroblasts, and a high mitotic rate. The differential diagnosis with florid follicular hyperplasia can be difficult. Stains for $b c l-2$, commonly employed in the diagnosis of FL, are not helpful. Documentation of monoclonality, either by light-chain expression or molecular studies, is most useful in diagnosis. Some cases appear to show evidence of plasmacytoid differentiation, and therefore, immunohistochemistry in paraffin sections may be useful. FL in children usually presents with localized disease and has an excellent prognosis (7). It is more common in males than 
TABLE 3. Characteristics of Pediatric Follicular Lymphoma: a Distinctive Disease Entity

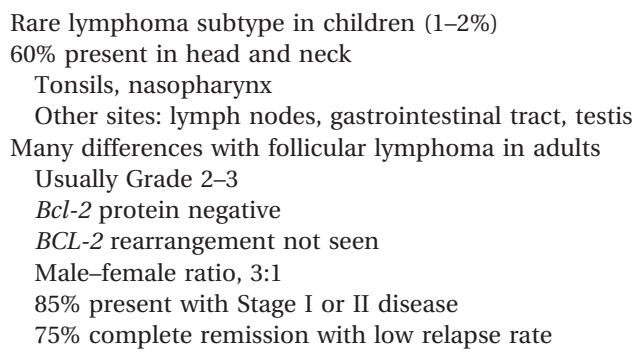

females (M:F ratio, 3:1), in contrast in adult follicular lymphomas, which show a slightly greater prevalence in females.

The Revised European-American Lymphoma classification (8), and its successor, the World Health Organization classification of tumors of the hematopoietic and lymphoid tissues (9), have as a basic principle the recognition of specific disease entities by use of morphologic, clinical, immunophenotypic, and genotypic criteria. By this standard, pediatric follicular lymphomas should be considered a separate disease entity from the more common follicular lymphomas seen in adults. These tumors have a different molecular pathogenesis from adult follicular lymphomas, and the majority of patients will have a sustained complete clinical remission with appropriate treatment. Bone marrow involvement is rare, and presentation in extranodal sites, such as the testis or gastrointestinal tract, is not uncommon. They do seem to be of germinal center origin, based on the expression of bcl- 6 by the neoplastic cells (10).

Although Hodgkin's disease (HD) overall is rare in Waldeyer's ring, occasional cases of HD have been reported in this site (11). Epstein-Barr virus (EBV) appears to be more often found in the neoplastic cells in contrast to HD presenting in other sites. This finding may relate to the nasopharynx as a reservoir for EBV. Most reported patients had localized disease, Stage I or II. Nodular lymphocyte predominant HD also may occur but is rare.

Diverse lymphomas of both $\mathrm{T}$ and B-cell types also occur in this site. These include T-cell-rich large B-cell lymphomas, diffuse large B-cell lymphoma, peripheral T-cell lymphoma, unspecified, and specific types of T-cell malignancy, such as adult T-cell lymphoma/leukemia (12-14).

\section{EXTRANODAL LYMPHOMAS OF THE SINONASAL AND ORAL REGIONS}

In contrast to the nasopharynx itself, T-cell or natural killer (NK)-cell lymphomas, rather than B-cell lymphomas, more often affect the sinonasal area and palate. The most common lymphoma in this site is nasal NK/T-cell lymphoma. However, B-cell lymphomas, including plasmablastic lymphoma and Burkitt lymphoma, may present with gingival involvement. Burkitt lymphoma involving the gingiva usually represents extension from the mandible or maxilla.

Extranodal NK/T-cell lymphoma, nasal-type (nasal NK/T) was formerly known as angiocentric lymphoma because of the propensity of this tumor to show angioinvasion and necrosis. However, because angioinvasion is not seen in all cases, and because other pathogenetic mechanisms have been implicated in causing the necrosis, the name extranodal NK/T-cell lymphoma, nasal type, was proposed in the WHO classification $(9,15)$. It is a distinct clinicopathologic entity highly associated with EBV (16-19).

The most common clinical presentation is with a destructive nasal or midline facial tumor, so-called lethal midline granuloma. Palatal destruction, orbital swelling, and edema may be prominent (20). Nasal NK/T lymphomas often spread to other extranodal sites, including skin, soft tissue, testis, upper respiratory tract, and gastrointestinal tract. Tumors with an identical phenotype and genotype may appear primarily outside the nasal region. For this reason, the term extranodal NK/T-cell lymphoma, nasal type is preferred. Additionally, there are aggressive NK and NK-like T-cell leukemias that have a similar phenotype and genotype (21). Most of these cases also are EBV positive, suggestive that they might represent a leukemic counterpart of this disease $(19,21,22)$.

Nasal NK/T-cell lymphoma is characterized by a broad cytologic spectrum. The atypical cells may be small or medium in size. Large atypical and hyperchromatic cells may be admixed, or may predominate. If the small cells are in the majority, the disease may be difficult to distinguish from an inflammatory or infectious process. In early stages, there may also be a prominent admixture of inflammatory cells, further causing difficulty in diagnosis (23). Necrosis, with or without evidence of angioinvasion, is seen in 50-60\% of nasal NK/T-cell lymphoma. The presence of extensive necrosis can make diagnosis difficult, especially in small biopsy specimens. Multiple biopsies are sometimes required for correct diagnosis.

Because all cases of nasal NK/T-cell lymphoma are positive for EBV, in situ hybridization studies with probes to EBV-encoded small nuclear RNA (EBER 1/2) may be very helpful in diagnosis and can detect even small numbers of neoplastic cells $(24,25)$. However, LMP-1 is not a sensitive indicator of EBV positivity, and is often negative.

Although the cells express some T-cell-associated antigens, most commonly CD 2, other T-cell markers, such as surface CD 3, are usually absent (18). 
Cytoplasmic CD 3 can be found in paraffin sections. However, cytoplasmic CD 3 can be found in NK cells and is not specific for a T-cell lineage. In addition, molecular studies in most cases have not shown a clonal T-cell gene rearrangement, despite clonality being shown by other methods $(17,26$, 27). In favor of an NK-cell origin, the cells are nearly always CD 56+; however, CD 16 and CD 57, other NK-cell antigens, are usually negative. Rare cases with identical histologic and clinical features may be of true T-cell derivation. Thus, the term NK/Tcell lymphoma is favored. Both NK and T-cell variants are EBV positive (28-30).

Little is known about the molecular pathogenesis of nasal NK/T-cell lymphoma. However, a few studies have shown some recurring cytogenetic abnormalities, both by conventional cytogenetics and comparative genomic hybridization (31-33). p53 mutations and deletions are a common feature, as well as overexpression of the p53 protein (34). Frequent deletions at $6 \mathrm{q}$ and $13 \mathrm{q}$ have been found.

Nasal NK/T-cell lymphoma is much more common in Asians than in individuals of European background. Clusters of the disease have also been reported in Central and South America and in Mexico, in individuals of Native American heritage (35, 36). Thus, a racial predisposition appears to play a role in the pathogenesis of angiocentric NK/T-cell lymphoma.

Nasal disease may be controlled with radiotherapy, but the relapse rate is high. Chemotherapy is generally used in conjunction with radiation therapy, but many cases are chemotherapy resistant. The neoplastic cells are frequently positive for p53, which has been associated with resistance to therapy in other lymphomas (34). The most common site of relapse is skin and subcutaneous tissue. A hemophagocytic syndrome is a common clinical complication, which adversely affects survival in angiocentric NK/T-cell lymphoma (37). It is likely that EBV plays a role in the pathogenesis of the hemophagocytic syndrome.

Not all T-cell lymphomas occurring in the nasal region are nasal NK/T-cell lymphomas. Peripheral T-cell lymphomas of other types, (peripheral T-cell, unspecified, anaplastic large-cell lymphoma) may also be seen. These tumors are generally EBV negative and may or may not have a cytotoxic T-cell immunophenotype (38-40). In addition, B-cell lymphomas, most commonly aggressive B-cell lymphomas, may be seen $(38,41)$.

Lymphomatoid granulomatosis (LYG) exhibits many similarities both clinically and pathologically to extranodal NK/T-cell lymphoma, nasal type (42). In the past, it was considered to be part of the same disease spectrum, angiocentric immunoproliferative lesions (AIL; 23, 43). However, recent data indicate that LYG is an EBV-positive B-cell prolifera- tion associated with an exuberant $\mathrm{T}$-cell reaction $(44,45)$.

LYG also presents in extranodal sites, but the most common site of involvement is the lung $(45,46)$. The kidney and central nervous system are also frequently involved, as are skin and subcutaneous tissue. The pattern in necrosis in both LYG and NK/T-cell lymphoma is very similar, emphasizing the role of EBV in mediating the vascular damage (15).

LYG is rare in the nasal area. However, we have encountered EBV-positive lymphoproliferative disorders with features of LYG commonly in the oral cavity and gingival region (Fig. 1). They usually contain marked necrosis. As with LYG in other sites, immunodeficiency is a predisposing feature. These lesions may occur in the setting of HIV, and in patients receiving iatrogenic immunosuppression for other disorders (methotrexate, steroids).

Plasmablastic lymphoma, a variant of diffuse large B-cell lymphoma, often presents in the oral cavity. These lymphomas are usually positive for EBV and also occur in a setting of immunodeficiency, most commonly HIV infection (47). The most common sites of involvement are the gingiva, floor of the mouth, and palate. Plasmablastic lymphomas are more monomorphic than LYG, without an inflammatory background. They also lack the vascular destruction and necrosis frequently seen in LYG. They exhibit an aggressive clinical course, with frequent spread to other extranodal and nodal sites in most patients.

The cells typically have a markedly plasmacytoid appearance. As expected for cells with plasmacytic differentiation, they are typically CD20 negative but express the plasma cell-associated marker VS38c + , which is found in cells equipped for protein production with abundant rough endoplasmic reticulum. EBV has been identified in approximately $60 \%$ of cases (47). Although many cases will contain monoclonal Ig sequences, some cases appear Ig negative. EBV often interferes with the ability of a cell to produce Ig and also leads to the downregulation of other B-cell associated antigens (48).

The differential diagnosis of Wegener's granulomatosis with nasal NK/T-cell lymphoma presents a more significant issue. The majority of patients with Wegener's granulomatosis present with head and neck disease. The nasal and paranasal sinuses are most commonly affected, but other sites may be involved, including the larynx, oral region, periorbital region, middle and external ear, and salivary gland (49).

The histological features usually permit the differential diagnosis of Wegener's granulomatosis and LYG, despite clinical similarities. Lymphoid cells usually do not form a significant component of the infiltrate. The most common histologic features of Wegener's granulomatosis are vasculitis, necro- 

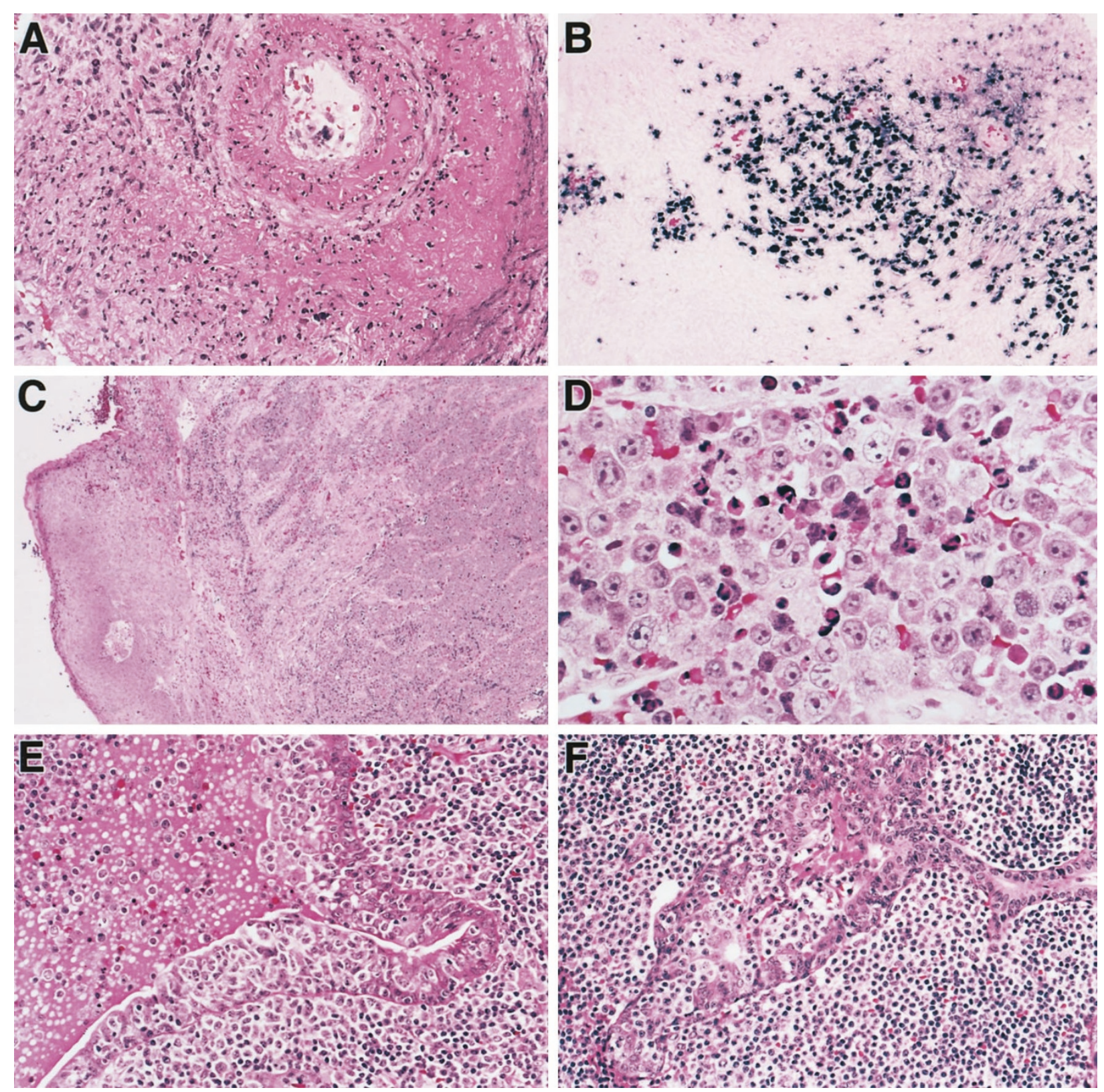

FIGURE 1. Lymphoid lesions of the head and neck. A and B, EBV-associated B-cell lymphoproliferative process presenting as a gingival lesion. This lesion has some features of lymphomatoid granulomatosis, including marked necrosis and vascular damage. B, the EBER1 in situ hybridization shows scattered positive cells, more numerous around blood vessels. $\mathbf{C}$ and $\mathbf{D}$, plasmablastic lymphoma of the oral cavity. A dense monomorphic infiltrate is seen beneath the oral mucosa. The cells have an immunoblastic or plasmablastic appearance and were CD20 negative and EBER positive. E, lymphoepithelial cyst of the salivary gland in an HIV-positive patient. Lymphoid cells with clear cytoplasm infiltrate the epithelium. F, extranodal marginal-zone lymphoma of the salivary gland. Broad coronas of monocytoid cells surround the altered ducts.

sis, and granulomatous inflammation. However, it is rare that all of these features are seen in a single biopsy specimen (49). Neutrophils are usually abundant, in contrast to their rarity in nasal NK/Tcell lymphoma. The absence of EBV-positive cells in the infiltrate is another helpful diagnostic feature (24).

Salivary Gland Lymphoid Hyperplasia and Lymphoma

Lymphoid hyperplasia affecting the salivary glands and periparotid lymph nodes is commonly seen in the setting of HIV infection $(50,51)$. The parotid gland is most often affected, but other salivary glands may be involved as well. The lesions are cystic in nearly $100 \%$ of cases, in contrast to SS, in which cysts are found in only $3 \%$ (52). The salivary gland and adjacent lymph nodes are affected by marked lymphoid hyperplasia with features of HIV-associated lymphadenopathy. In a careful study performed by Ihrler et al., they showed that the cystic lesions are of true salivary origin and not derived from salivary gland rests within periparotid lymph nodes (52). The cysts are composed of epi- 
thelial cells from the striated ducts of the salivary gland. Lymphoepithelial lesions may be seen, but monocytoid B cells are not prominent. Compression of salivary gland ducts by markedly hyperplastic lymphoid tissue may play a role in the evolution of the cystic lesions but is unlikely to fully explain their pathogenesis. The lymphoid infiltrates are polyclonal and generally do not progress to lymphoma. Of course, patients with HIV infection are at increased risk for development of aggressive B-cell lymphomas, most commonly Burkitt lymphoma and diffuse large-cell lymphoma.

In pediatric patients with HIV infection, lymphoepithelial cystic lesions of the salivary gland may more closely resemble MALT lymphomas, and monoclonality may be found (53). Interestingly, despite the rarity of MALT lymphomas in children, MALT lymphomas have been described at a variety of sites (lung, salivary gland, and stomach) in pediatric patients with HIV (54). The salivary gland infiltrates in pediatric HIV disease show some similarities to lymphocytic interstitial pneumonitis (LIP) and cystic hyperplasia of the thymus gland seen in this clinical setting (55-57).

The most common lymphoid lesion of the salivary gland is lymphoepithelial sialadenitis (LESA). (58). This term was recently proposed as an alternative to myoepithelial sialadenitis and benign lymphoepithelial lesion (BLEL), based on the absence of true myoepithelial cells in these lesions and confusing nature of the last term (BLEL), as many of the cases described as BLEL were probably lymphomas.

LESA is most commonly seen in the setting of SS. Similar infiltrates affect the lacrimal glands in many patients, producing the clinical picture of dry eyes and dry mouth. In LESA, markedly hyperplastic lymphoid tissue infiltrates the salivary gland, with loss of most acinar structures. The altered ducts are surrounded by and infiltrated by lymphoid cells. Within the ducts themselves, monocytoid B cells may be prominent, even in the absence of lymphoma. However, if the ducts are surrounded by broad coronas of monocytoid cells, the index of suspicion for extranodal marginal zone lymphoma of MALT-type, so-called MALT lymphoma, should be raised $(1,59)$. Other worrisome features favoring MALT lymphoma over LESA include extensive infiltration of the interfollicular region by monocytoid cells or atypical plasma cells containing Dutcher bodies (59).

Early studies showed that patients with SS were at increased risk for B-cell lymphomas (60). These were generally aggressive B-cell lymphomas outside the salivary gland; the low-grade lymphoproliferative process in the salivary gland itself had not been recognized as malignant. It was only later that the salivary gland lesions with features of LESA were shown to harbor monoclonal B-cell populations (61). Despite the presence of monoclonality at the genetic level, the infiltrates usually pursued a benign clinical course, and in fact different clones could be found at different points in time. This situation is analogous to lymphocytic gastritis associated with Helicobacter pylori, which can show monoclonality by polymerase chain reaction (PCR)-based techniques in the absence of overt lymphoma. Therefore, finding a clone by PCR alone is not sufficient to diagnosis MALT lymphoma in the salivary gland in the absence of other evidence of malignancy (62). More than 50\% of cases of LESA will contain monoclonal B cells by PCR, in the absence of histological or clinical features of lymphoma.

The demonstration of monoclonality at the immunophenotypic level, either by flow cytometry or immunohistochemistry, is stronger evidence of progression to lymphoma $(63,64)$. In addition, if regional lymph nodes contain sinusoidal and parasinusoidal infiltrates of monocytoid B cells, this finding favors MALT lymphoma, as it indicates spread beyond the salivary gland (65). The risk of lymphoma in LESA and SS has been estimated at $4-7 \%$ (58). MALT lymphoma begins as an antigendriven lymphoid proliferation, which progresses first to monoclonality and then, with the acquisition of secondary genetic changes, to MALT lymphoma (1). The development of an aggressive B-cell lymphoma is associated with an adverse prognosis (66).

Immunophenotype is helpful in the differential diagnosis of MALT lymphomas from cytologically similar lymphomas such as B-CLL/SLL and MCL. MALT lymphomas are positive for B-cell-associated antigens CD 19, CD 20, and CD 22 but are usually negative for $\mathrm{CD} 5$, in contrast to most systemic small lymphocytic malignancies. Rare cases of MALT lymphoma may be CD5 positive $(67,68)$. They are negative for CD10 and cyclin D 1.

MALT lymphomas also have a commonly recurring cytogenetic abnormality, the $t(11 ; 18)$ observed in up to $50 \%$ of extranodal cases $(69-71)$. The genes involved in the translocation have been identified as $c-I A P 2$, a gene encoding for an inhibitor of apoptosis, and a novel gene on 18q21 named MLT (of unknown function; 70, 72). It has been speculated that the fusion protein may lead to increased inhibition of apoptosis conferring a survival advantage to the neoplastic cells.

The translocation $\mathrm{t}(11 ; 18)(\mathrm{q} 21 ; \mathrm{q} 21)$ is associated exclusively with low-grade extranodal MALT, and it is not detected in cases with simultaneous low, and high grade tumors or in "primary" extranodal largecell lymphomas, raising the question of whether these primary extranodal B-cell lymphomas are related to low-grade MALT. The translocation is found in tumors of the salivary gland and lacrimal gland, as well as other MALT-associated sites (73). Identification of this genetic abnormality may 
prove to be of diagnostic utility in distinguishing LESA with a small monoclonal B-cell population from true MALT lymphoma with the potential for spread outside the salivary gland. MALT lymphomas tend to spread to regional lymph nodes, as well as other extranodal sites, including the stomach, lung, and bladder. The putative cell of origin of marginal zone lymphomas is a memory B cell (postgerminal center; 74, 75).

Warthin's tumor contains variable amounts of lymphoid tissue. It can be a site of involvement by malignant lymphoma and, rarely, malignant lymphoma may present in a Warthin's tumor. The most common lymphoma in this site is follicular lymphoma $(76,77)$. Hodgkin's lymphoma is occasionally seen (78).

\section{REFERENCES}

1. Isaacson PG. Mucosa-associated lymphoid tissue lymphoma. Semin Hematol 1999;36(2):139-47.

2. O'Briain D, Kennedy M, Daly P, O'Brian A, Tanner W, Rogers $\mathrm{P}$, et al. Multiple lymphomatous polyposis of the gastrointestinal tract: a clinicopathologically distinctive form of nonHodgkin's lymphoma of centrocytic type. Am J Surg Pathol 1989;13:691-9.

3. Zucca E, Fontana S, Roggero E, Pedrinis E, Pampallona S, Cavalli F. Treatment and prognosis of centrocytic (mantle cell) lymphoma: a retrospective analysis of twenty-six patients treated in one institution. Leuk Lymphoma 1994;13(12):105-10.

4. Romaguera J, Dang N, Hagemeister FB, McLaughlin P, Pro B, Rodriguez J, et al. Evidence for need of upper and lower endoscopies with biopsy in staging of asymptomatic patients with aggressive mantle cell lymphoma (MCL). Blood 2000; 96(11 Suppl):334a.

5. Campo E, Raffeld M, Jaffe ES. Mantle-cell lymphoma. Semin Hematol 1999;36(2):115-27.

6. Pinto A, Hutchison RE, Grant LH, Trevenen CL, Berard CW. Follicular lymphomas in pediatric patients. Mod Pathol 1990;3(3):308-13.

7. Atra A, Meller ST, Stevens RS, Hobson R, Grundy R, Carter $\mathrm{RL}$, et al. Conservative management of follicular nonHodgkin's lymphoma in childhood. Br J Haematol 1998; 103(1):220-3.

8. Harris NL, Jaffe ES, Stein H, Banks PM, Chan JK, Cleary ML, et al. A revised European-American classification of lymphoid neoplasms: a proposal from the International Lymphoma Study Group. Blood 1994;84(5):1361-92.

9. Jaffe ES, Harris NL, Stein H, Vardiman J. Pathology and genetics of tumours of haematopoietic and lymphoid tissues. Lyon, France: IARC Press; 2001.

10. Finn LS, Viswanatha DS, Belasco JB, Snyder H, Huebner D, Sorbara L, et al. Primary follicular lymphoma of the testis in childhood. Cancer 1999;85(7):1626-35.

11. Kapadia SB, Roman LN, Kingma DW, Jaffe ES, Frizzera G. Hodgkin's disease of Waldeyer's ring. Clinical and histoimmunophenotypic findings and association with Epstein-Barr virus in 16 cases. Am J Surg Pathol 1995;19(12):1431-9.

12. Dargent JL, Roufosse C, Remmelink M, Neve P. Primary T-cell-rich B-cell lymphoma of the Waldeyer's ring: a pathologic condition more frequent than presupposed? [letter]. Am J Surg Pathol 1998;22(5):638-40.

13. Tomita Y, Ohsawa M, Mishiro Y, Itokazu T, Kojya S, Noda Y, et al. Non-Hodgkin's lymphoma of Waldeyer's ring as a manifestation of lymphoproliferative diseases associated with human T-cell leukemia virus type 1 in southwestern Japan. Mod Pathol 1997;10(9):933-8.

14. Kojima M, Tamaki Y, Nakamura S, Hosomura Y, Kurabayashi $\mathrm{Y}$, Itoh $\mathrm{H}$, et al. Malignant lymphoma of Waldeyer's ring. A histological and immunohistochemical study. APMIS 1993; 101(7):537-44.

15. Teruya-Feldstein J, Jaffe ES, Burd PR, Kanegane H, Kingma $\mathrm{DW}$, Wilson $\mathrm{WH}$, et al. The role of Mig, the monokine induced by interferon-gamma, and IP-10, the interferongamma-inducible protein-10, in tissue necrosis and vascular damage associated with Epstein-Barr virus-positive lymphoproliferative disease. Blood 1997;90(10):4099-5105.

16. Chan J, Ng C, Lau W, Ho S. Most nasal/nasopharyngeal lymphomas are peripheral $\mathrm{T}$ cell neoplasms. Am J Surg Pathol 1987;11:418-29.

17. Ho F, Srivastava G, Loke S, Fu K, Leung B, Liang R, et al. Presence of Epstein-Barr virus DNA in nasal lymphomas of B and T cell type. Hematol Oncol 1990;8:271-81.

18. Jaffe ES, Chan JKC, Su IJ, Frizzera G, Mori S, Feller AC, et al. Report of the workshop on nasal and related extranodal angiocentric T/NK cell lymphomas: definitions, differential diagnosis, and epidemiology. Am J Surg Pathol 1996;20(1): 103-11.

19. Chan JK. Natural killer cell neoplasms. Anat Pathol 1998;3: 77-145.

20. Ho F, Choy D, Loke S, Kung I, Fu K, Liang R, et al. Polymorphic reticulosis and conventional lymphomas of the nose and upper aerodigestive tract—a clinicopathologic study of 70 cases, and immunophenotypic studies of 16 cases. Hum Pathol 1990;21:1041-50.

21. Imamura N, Kusunoki Y, Kawa-Ha K, Yumura K, Hara J, Oda $\mathrm{K}$, et al. Aggressive natural killer cell leukaemia/lymphoma: report of four cases and review of the literature. Possible existence of a new clinical entity originating from the third lineage of lymphoid cells. Br J Haematol 1990;75(1):49-59.

22. Jaffe ES. Classification of NK-cell and NK-like T-cell malignancies [editorial]. Blood 1996;87:1207-10.

23. Lipford EH, Margolick JB, Longo DL, Fauci AS, Jaffe ES. Angiocentric immunoproliferative lesions: a clinicopathologic spectrum of post-thymic $\mathrm{T}$ cell proliferations. Blood 1988;5:1674-81.

24. Dictor M, Cervin A, Kalm O, Rambech E. Sinonasal T-cell lymphoma in the differential diagnosis of lethal midline granuloma using in situ hybridization for Epstein-Barr virus RNA. Mod Pathol 1996;9:7-14.

25. Tsang WY, Chan JK, Yip TT, Ng CS, Wong KF, Poon YF, et al. In situ localization of Epstein-Barr virus encoded RNA in non-nasal/nasopharyngeal CD56-positive and CD56negative T-cell lymphomas. Hum Pathol 1994;25(8):758-65.

26. Medeiros LJ, Peiper SC, Elwood L, Yano T, Raffeld M, Jaffe ES. Angiocentric immunoproliferative lesions: a molecular analysis of eight cases. Hum Pathol 1991;22(11):1150-7.

27. Medeiros LJ, Jaffe ES, Chen YY, Weiss LM. Localization of Epstein-Barr viral genomes in angiocentric immunoproliferative lesions. Am J Surg Pathol 1992;16(5):439-47.

28. Jaffe ES, Krenacs L, Kumar S, Kingma DW, Raffeld M. Extranodal peripheral T-cell and NK-cell neoplasms. Am J Clin Pathol 1999;111(1 Suppl 1):S46-55.

29. Chiang AK, Srivastava G, Lau PW, Ho FC. Differences in T-cell-receptor gene rearrangement and transcription in nasal lymphomas of natural killer and T-cell types: implications on cellular origin. Hum Pathol 1996;27(7):701-7.

30. Arnulf B, Copie-Bergman C, Delfau-Larue MH, LavergneSlove A, Bosq J, Wechsler J, et al. Nonhepatosplenic gammadelta T-cell lymphoma: a subset of cytotoxic lymphomas with mucosal or skin localization. Blood 1998;91(5):1723-31. 
31. Wong KF, Zhang YM, Chan JK. Cytogenetic abnormalities in natural killer cell lymphoma/leukaemia-is there a consistent pattern? Leuk Lymphoma 1999;34(3-4):241-50.

32. Siu LL, Wong KF, Chan JK, Kwong YL. Comparative genomic hybridization analysis of natural killer cell lymphoma/leukemia. Recognition of consistent patterns of genetic alterations. Am J Pathol 1999;155(5):1419-25.

33. Cheng R, Guan X, Lau G, Chan J, Trent J, Zhuang Z, et al. Chromosome $1 \mathrm{p}$ terminal deletion and loss of chromosomes $17 \mathrm{p}$ and $16 \mathrm{p}$ are common findings in nasal NK/T cell lymphoma by comparative genomic hybridization [abstract]. Mod Pathol 1998;11:126A.

34. Quintanilla-Martinez L, Franklin JL, Guerrero I, Krenacs L, Naresh KN, Rama-Rao C, et al. Histological and immunophenotypic profile of nasal NK/T cell lymphomas from Peru: high prevalence of p53 overexpression. Hum Pathol 1999; 30(7):849-55.

35. Arber DA, Weiss LM, Albujar PF, Chen YY, Jaffe ES. Nasal lymphomas in Peru. High incidence of T-cell immunophenotype and Epstein-Barr virus infection. Am J Surg Pathol 1993;17(4):392-9.

36. Elenitoba-Johnson KSJ, Zarate-Osorno A, Meneses A, Krenacs L, Kingma DW, Raffeld M, et al. Cytotoxic granular protein expression, Epstein-Barr virus strain type, and latent membrane protein-1 oncogene deletions in nasal T-lymphocyte/natural killer cell lymphomas from Mexico. Mod Pathol 1998;11(8):754-61.

37. Jaffe ES, Costa J, Fauci AS, Cossman J, Tsokos M. Malignant lymphoma and erythrophagocytosis simulating malignant histiocytosis. Am J Med 1983;75(5):741-9.

38. Cuadra-Garcia I, Proulx GM, Wu CL, Wang CC, Pilch BZ, Harris NL, et al. Sinonasal lymphoma: a clinicopathologic analysis of 58 cases from the Massachusetts General Hospital. Am J Surg Pathol 1999;23(11):1356-69.

39. Coupland SE, Foss HD, Assaf C, Auw-Haedrich C, Anastassiou G, Anagnostopoulos I, et al. T-cell and T/natural killercell lymphomas involving ocular and ocular adnexal tissues: a clinicopathologic, immunohistochemical, and molecular study of seven cases. Ophthalmology 1999;106(11):2109-20.

40. Chim CS, Shek TW, Ooi GC, Liang R. CD-30 positive peripheral T-cell lymphoma of the Waldeyer's ring. Leuk Lymphoma 2000;38(1-2):199-202.

41. Frierson HF Jr, Innes DJ Jr, Mills SE, Wick MR. Immunophenotypic analysis of sinonasal non-Hodgkin's lymphomas. Hum Pathol 1989;20(7):636-42.

42. Katzenstein AA, Carrington CB, Liebow AA. Lymphomatoid granulomatosis: a clinicopathologic study of 152 cases. Cancer 1979;43:360-73.

43. DeRemee RA, Weiland LH, McDonald TJ. Polymorphic reticulosis, lymphomatoid granulomatosis. Two diseases or one? Mayo Clin Proc 1978;53(10):634-40.

44. Guinee DJ, Jaffe E, Kingma D, Fishback N, Wallberg K, Krishnan J, et al. Pulmonary lymphomatoid granulomatosis. Evidence for a proliferation of Epstein-Barr virus infected B-lymphocytes with a prominent T-cell component and vasculitis. Am J Surg Pathol 1994;18(8):753-64.

45. Jaffe ES, Wilson WH. Lymphomatoid granulomatosis: pathogenesis, pathology, and clinical implications. Cancer Surv 1997;30:233-48.

46. Katzenstein A-L, Peiper S. Detection Epstein-Barr genomes in lymphomatoid granulomatosis: analysis of 29 cases by the polymerase chain reaction. Mod Pathol 1990;3:435-41.

47. Delecluse HJ, Anagnostopoulos I, Dallenbach F, Hummel M, Marafioti T, Schneider U, et al. Plasmablastic lymphomas of the oral cavity: a new entity associated with the human immunodeficiency virus infection. Blood 1997;89(4):141320.

48. Ohshima K, Suzumiya J, Kanda M, Haraoka S, Kawasaki C, Shimazaki K, et al. Genotypic and phenotypic alterations in
Epstein-Barr virus-associated lymphoma. Histopathology 1999;35(6):539-50.

49. Devaney KO, Travis WD, Hoffman G, Leavitt R, Lebovics R, Fauci AS. Interpretation of head and neck biopsies in Wegener's granulomatosis. A pathologic study of 126 biopsies in 70 patients. Am J Surg Pathol 1990;14(6):555-64.

50. Ioachim HL, Ryan JR, Blaugrund SM. Salivary gland lymph nodes. The site of lymphadenopathies and lymphomas associated with human immunodeficiency virus infection. Arch Pathol Lab Med 1988;112(12):1224-8.

51. Ulirsch RC, Jaffe ES. Sjogren's syndrome-like illness associated with the acquired immunodeficiency syndrome-related complex. Hum Pathol 1987;18(10):1063-8.

52. Ihrler S, Zietz C, Riederer A, Diebold J, Lohrs U. HIV-related parotid lymphoepithelial cysts. Immunohistochemistry and 3-D reconstruction of surgical and autopsy material with special reference to formal pathogenesis. Virchows Arch 1996;429(2-3):139-47.

53. Joshi VV, Gagnon GA, Chadwick EG, Berard CW, McClain KL, Leach CT, et al. The spectrum of mucosa-associated lymphoid tissue lesions in pediatric patients infected with HIV: A clinicopathologic study of six cases. Am J Clin Pathol 1997;107(5):592-600.

54. Teruya-Feldstein J, Temeck BK, Sloas MM, Kingma DW, Raffeld M, Pass HI, et al. Pulmonary malignant lymphoma of mucosa-associated lymphoid tissue (MALT) arising in a pediatric HIV-positive patient. Am J Surg Pathol 1995;19(3): 357-63.

55. Mishalani SH, Lones MA, Said JW, Cesarman E, Chang Y, Moore PS, et al. Multilocular thymic cyst. A novel thymic lesion associated with human immunodeficiency virus infection Kaposi's sarcoma-associated herpesvirus-like DNA sequences in AIDS-related body-cavity-based lymphomas. Arch Pathol Lab Med 1995;119(5):467-70.

56. Kontny HU, Sleasman JW, Kingma DW, Jaffe ES, Avila NA, Pizzo PA, et al. Multilocular thymic cysts in children with human immunodeficiency virus infection: clinical and pathologic aspects. J Pediatr 1997;131(2):264-70.

57. Griffiths MH, Miller RF, Semple SJ. Interstitial pneumonitis in patients infected with the human immunodeficiency virus. Thorax 1995;50(11):1141-6.

58. Harris NL. Lymphoid proliferations of the salivary glands. Am J Clin Pathol 1999;111(1 Suppl 1):S94-103.

59. Harris NL, Isaacson PG. What are the criteria for distinguishing MALT from non-MALT lymphoma at extranodal sites? Am J Clin Pathol 1999;111(1 Suppl 1):S126-32.

60. Zulman J, Jaffe R, Talal N. Evidence that the malignant lymphoma of Sjogren's syndrome is a monoclonal B-cell neoplasm. N Engl J Med 1978;299:1215-20.

61. Fishleder A, Tubbs R, Hesse B, Levine H. Uniform detection of immunoglobulin-gene rearrangement in benign lymphoepithelial lesions. N Engl J Med 1987;316:1118-21.

62. Bahler DW, Swerdlow SH. Clonal salivary gland infiltrates associated with myoepithelial sialadenitis (Sjogren's syndrome) begin as nonmalignant antigen-selected expansions. Blood 1998;91(6):1864-72.

63. Hsi E, Zukerberg L, Schnitzer B, Harris N. Development of extrasalivary gland lymphoma in myoepithelial sialadenitis. Mod Pathol 1995;8:817-24.

64. Quintana PG, Kapadia SB, Bahler DW, Johnson JT, Swerdlow SH. Salivary gland lymphoid infiltrates associated with lymphoepithelial lesions: a clinicopathologic, immunophenotypic, and genotypic study. Hum Pathol 1997;28(7):850-61.

65. Sheibani K, Burke J, Swartz W, Nademanee A, Winberg C. Monocytoid B cell lymphoma. Clinicopathologic study of 21 cases of a unique type of low grade lymphoma. Cancer 1988;62:1531-8.

66. Voulgarelis M, Dafni UG, Isenberg DA, Moutsopoulos HM. Malignant lymphoma in primary Sjogren's syndrome: a mul- 
ticenter, retrospective, clinical study by the European Concerted Action on Sjogren's Syndrome. Arthritis Rheum 1999; 42(8):1765-72.

67. Ferry JA, Yang WI, Zukerberg LR, Wotherspoon AC, Arnold A, Harris NL. CD5+ extranodal marginal zone B-cell (MALT) lymphoma. A low grade neoplasm with a propensity for bone marrow involvement and relapse. Am J Clin Pathol 1996;105(1):31-7.

68. Ballesteros E, Osborne BM, Matsushima AY. CD5+ lowgrade marginal zone B-cell lymphomas with localized presentation. Am J Surg Pathol 1998;22(2):201-7.

69. Horsman D, Gascoyne R, Klasa R, Coupland R. t(11;18)(q21; q21.1): a recurring translocation in lymphomas of mucosaassociated lymphoid tissue (MALT). Genes Chromosom Cancer 1992;4(2):183-7.

70. Dierlamm J, Baens M, Wlodarska I, Stefanova-Ouzounova M, Hernandez JM, Hossfeld DK, et al. The apoptosis inhibitor gene API2 and a novel 18q gene, MLT, are recurrently rearranged in the $\mathrm{t}(11 ; 18)(\mathrm{q} 21 ; \mathrm{q} 21)$ associated with mucosa-associated lymphoid tissue lymphomas. Blood 1999;93(11):3601-9.

71. Rosenwald A, Ott G, Stilgenbauer S, Kalla J, Bredt M, Katzenberger T, et al. Exclusive detection of the $\mathrm{t}(11 ; 18)(\mathrm{q} 21$; q21) in extranodal marginal zone B cell lymphomas (MZBL) of MALT type in contrast to other MZBL and extranodal large B cell lymphomas. Am J Pathol 1999;155(6):1817-21.

72. Akagi T, Motegi M, Tamura A, Suzuki R, Hosokawa Y, Suzuki $\mathrm{H}$, et al. A novel gene, MALT1 at 18q21, is involved in $\mathrm{t}(11 ; 18)$ (q21;q21) found in low-grade B-cell lymphoma of mucosaassociated lymphoid tissue. Oncogene 1999;18(42):5785-94.

73. Remstein ED, James CD, Kurtin PJ. Incidence and subtype specificity of API2-MALT1 fusion translocations in extranodal, nodal, and splenic marginal zone lymphomas. Am J Pathol 2000;156(4):1183-8.

74. Du M, Diss TC, Xu C, Peng H, Isaacson PG, Pan L. Ongoing mutation in MALT lymphoma immunoglobulin gene suggests that antigen stimulation plays a role in the clonal expansion. Leukemia 1996;10(7):1190-7.

75. Tierens A, Delabie J, Pittaluga S, Driessen A, DeWolf-Peeters C. Mutation analysis of the rearranged immunoglobulin heavy chain genes of marginal zone cell lymphomas indicates an origin from different marginal zone B lymphocyte subsets. Blood 1998;91(7):2381-6.

76. Griesser GH, Hansmann ML, Bogman MJ, Pielsticker K, Lennert K. Germinal center derived malignant lymphoma in cystadenolymphoma. Virchows Arch A Pathol Anat Histopathol 1986;408(5):491-6.

77. Medeiros LJ, Rizzi R, Lardelli P, Jaffe ES. Malignant lymphoma involving a Warthin's tumor: a case with immunophenotypic and gene rearrangement analysis. Hum Pathol 1990;21(9):974-7.

78. Badve S, Evans G, Mady S, Coppen M, Sloane J. A case of Warthin's tumour with coexistent Hodgkin's disease. Histopathology 1993;22(3):280-1. 